Correspondence

Joël Renaudin

renaudin@bordeaux.inra.fr
Received 11 April 2008

Revised 12 June 2008

Accepted 16 June 2008

\section{Characterizing the replication and stability regions of Spiroplasma citri plasmids identifies a novel replication protein and expands the genetic toolbox for plant-pathogenic spiroplasmas}

\author{
Marc Breton, ${ }^{1,2}$ Sybille Duret, ${ }^{1,2}$ Nathalie Arricau-Bouvery, ${ }^{1,2}$ \\ Laure Béven ${ }^{1,2}$ and Joël Renaudin ${ }^{1,2}$ \\ ${ }^{1}$ INRA, UMR 1090 Génomique Diversité et Pouvoir Pathogène, F-33883 Villenave d'Ornon, France \\ ${ }^{2}$ Université de Bordeaux 2, UMR 1090 Génomique Diversité et Pouvoir Pathogène, F-33883 \\ Villenave d'Ornon, France
}

\begin{abstract}
Spiroplasma citri strain GII3 contains seven plasmids, pSciA and pSci1-6, that share extensive regions of sequence homology and display a mosaic gene organization. Plasmid pSci2 comprises 12 coding sequences (CDS), three of which encode polypeptides homologous to proteins Soj/ ParA, involved in chromosome partitioning, and TrsE and Mob/TraG, implicated in the type IV secretion pathway. One CDS encodes the adhesin-like protein ScARP3d whereas the other eight encode polypeptides with no homology to known proteins. The pSci2 CDS $p E$ and soj have counterparts in all seven plasmids. Through successive deletions, various pSci2 derivatives were constructed and assessed for their ability to replicate by transformation of $S$. citri 44 , a strain which has no plasmid. The smallest functional replicon was found to contain a single CDS $(p E)$ and its flanking intergenic regions. Shuttle (S. citrilEscherichia coli) plasmids, in which CDS $p E$ was disrupted, failed to replicate in S. citri, suggesting that PE is the replication protein of the $S$. citri plasmids. Successive propagations of pSci2-derived transformed spiroplasmas, in the absence of selection pressure, revealed that only pSci2 derivatives having an intact soj gene were stably maintained, indicating that the soj-encoded polypeptide is most likely involved in plasmid partitioning. Upon transformation, pSci2 derivatives, including shuttle (S. citrilE. coli) plasmids, were shown to replicate in all $S$. citri strains tested regardless of whether the strain possesses endogenous plasmids, such as strain GIl3, or not, such as strain R8A2. In addition, the pSci replicons were introduced efficiently into the plant-pathogenic spiroplasmas Spiroplasma kunkelii and Spiroplasma phoeniceum, the transformation of which had never, to our knowledge, been described before. These studies show that, besides their implications for the biology of $S$. citri, the pSci plasmids hold considerable promise as vectors of general use for genetic studies of plantpathogenic spiroplasmas. As an example, a HA-tagged $S$. citri protein was expressed in $S$.

kunkelii. Detection of $p E$-hybridizing sequences in various group I spiroplasma species indicated that $p E$ replicating plasmids were not restricted to the three plant-pathogenic spiroplasmas.
\end{abstract}

\section{INTRODUCTION}

Spiroplasmas are a group of helical, cell-wall-free bacteria belonging to the class Mollicutes. Three spiroplasma species, Spiroplasma citri (Saglio et al., 1973), Spiroplasma kunkelii (Whitcomb et al., 1986) and Spiroplasma phoeniceum (Saillard et al., 1987), have been associated with plant diseases. S. citri is the aetiological agent of the citrus stubborn and horseradish brittle root diseases and was the

Abbreviation: CDS, coding sequence(s).

Five supplementary figures and a supplementary table are available with the online version of this paper. first plant mollicute to be cultured in vitro (Fletcher et al., 1981; Saglio et al., 1971). Since then, S. citri has been studied extensively (Bové et al., 1989, 2003). The availability of both an experimental transmission assay via the leafhopper vector (Foissac et al., 1996) and gene transfer systems (Foissac et al., 1997; Renaudin, 2002; Renaudin \& Lartigue, 2005) has made it a unique model for studying plant mollicute-host interactions (André et al., 2005; Berho et al., 2006a; Bové et al., 2003; Killiny et al., 2005).

In spiroplasmas, plasmids were first detected as extrachromosomal, covalently-closed-circular DNAs (Ranhand 
et al., 1980) and some of them were mapped and/or cloned in Escherichia coli (Archer et al., 1981; Mouchès et al., 1983a). Extrachromosomal DNAs, including plasmids and viral DNAs, were most frequently detected in group I spiroplasmas (Gasparich et al., 1993), especially in S. citri strains. However, these plasmids have for a long time been designated cryptic since no phenotypic character had been associated with their presence. In addition, due to the lack of sequence and functional data, the engineering of natural plasmids to produce cloning vectors has had very limited success (Salvado et al., 1989). More recently sequencing of plasmids pBJS-O from S. citri strain BR3-3X (Joshi et al., 2005), and pSciA and pScil-6 from S. citri GII3 (Saillard et al., 2008), revealed that they encode proteins, including adhesin-like molecules, which have been tentatively associated with insect transmission (Killiny et al., 2006; Yu et al., 2000). Furthermore, it was shown that plasmids pSci1-6 from the insect-transmissible strain GII3 were absent in the non-insect-transmissible strains of $S$. citri (Berho et al., 2006b). However, the first clear-cut evidence of a phenotypic trait associated with spiroplasmal plasmids was the finding that pSci6 from S. citri GII3 conferred insect-transmissibility to the plasmid-free, non-insecttransmissible strain 44 (Berho et al., 2006a). Besides assessing their role in insect transmission, the successful transfer of pSci plasmids between strains of $S$. citri raised their potential as genetic tools. In addition to adhesin-like proteins, pScil-6 encode proteins with similarities to components of bacterial type IV secretion systems, suggesting the possibility of conjugative transfer of these plasmids. In turn, none of the plasmid-encoded proteins shared similarity with known replication proteins (Saillard et al., 2008).

Previously, we showed that sequences essential for replication and maintenance of pSci2 in $S$. citri were located within an $8 \mathrm{kbp}$ restriction fragment (Berho et al., 2006a). In the present study, we describe the functional characterization of the replication and stability regions of S. citri pSci-derived plasmids, with the aim of further investigating their role in spiroplasmal biology. We also demonstrate the usefulness of pSci-derived plasmids as vectors for gene transfer and expression in plant-pathogenic spiroplasmas other than $S$. citri.

\section{METHODS}

Spiroplasma strains, growth conditions and transformation. $S$. citri GII3 wild-type strain was originally isolated from its leafhopper vector Circulifer haematoceps, captured in Morocco (Vignault et al., 1980). S. citri 44 was isolated from a stubborn-diseased sweet orange tree in Iran (Hosseini Pour, 2000). Other spiroplasma strains used in this study are listed in Supplementary Table S1, available with the online version of this paper. Spiroplasmas were grown at $32{ }^{\circ} \mathrm{C}$ in SP4 medium (Whitcomb, 1983) from which fresh yeast extract was omitted. Spiroplasma cells were transformed by electroporation (Stamburski et al., 1991) using 2-10 $\mu$ g purified plasmid or various ligation mixtures. Spiroplasmal transformants were selected in the presence of $2 \mu \mathrm{g}$ tetracycline $\mathrm{ml}^{-1}$, and further propagated in broth medium containing $5 \mu \mathrm{g}$ tetracycline $\mathrm{ml}^{-1}$. The Spiroplasma species of tetracycline-resistant transformants were confirmed by PCR-RFLP analysis of the spiralin genes, using amplification with primer pair SR28/SR29 (Table 1) and digestion with $\mathrm{MboI}$ and/or RsaI.

Plasmid constructs. Plasmids pSRT1 and pSRT2 are $\mathrm{pBS}^{+}$ (Stratagene)-derived, ColE1 replicons carrying the tetracycline resistance gene tet $M$ under the control of the spiralin gene promoter (Lartigue et al., 2002). Plasmid pSRT1 differs from pSRT2 in that the tet $M$ cassette is in the opposite orientation. Plasmids pScilNT and $\mathrm{pSci6PT}$ were obtained by inserting the tet $M$ cassette (as a $2.3 \mathrm{kbp} P s t \mathrm{I}$ fragment) into the Nsi and PstI sites of S. citri pScil and pSci6, respectively, whereas pSci21NT resulted from the combination of the tet $M$ cassette with the 8034 bp NsiI fragment of pSci2 (Berho et al., 2006a). In pScilNT $\Delta S$, the scarp3d gene was disrupted by inserting the 20 bp oligonucleotide duplex SBamF1/SBamR1 (Table 1) into the NheI site of pScilNT. Similarly, in pSci21NT $\Delta$ soj, the soj gene was disrupted by insertion of the $19 \mathrm{bp}$ SojBamF1/SojBamR1 duplex into the SmlI site of pSci21NT. As a result, the Soj coding sequence (CDS) encodes a truncated polypeptide of 67 amino acids as compared with 260 in the wild-type. Plasmid pFL3 was obtained by self-ligation of the $6675 \mathrm{bp}$ EcoRI-BglII fragment of pSci21NT. Plasmid pFL4 was constructed by deleting the $891 \mathrm{bp} \mathrm{HincII-HaeIII}$ fragment within the mob gene of pFL3, and pFL5 by deletion of the $504 \mathrm{bp} A c l$ I-EcoRV fragment of pFL4. Plasmid pBS1 was derived from $\mathrm{pBS}^{+}$by inserting the EPBg1/ $\mathrm{EPBg} 2$ duplex at the EcoRI site to introduce a BglII site. Plasmid pBST1 was then obtained by combining the BglII-linearized pBS1 with the tet $M$ cassette (as a 2311 bp BamHI-BglII fragment) of pSRT2. Plasmid pFL6, containing the $p E$ gene and the flanking, intergenic regions, resulted from the ligation of the $2265 \mathrm{bp} \mathrm{PacI}$ fragment from pFL4 to the $2329 \mathrm{bp} P a c I$ fragment of pBST1 containing the tet $M$ cassette. Plasmid pFL7 (4259 bp) was obtained by deleting the $341 \mathrm{bp}$ AclI-BglII fragment of pFL6. The shuttle (S. citri/E. coli) plasmid pBSFL6 resulted from the combination of PstI-linearized $\mathrm{pBS}^{+}$and pFL6. To construct pSDE1, the amplification product of pSci2 with primer pair PEF1/ IEFR2 was inserted into pSRT1 after they were both digested with BamHI +EcoRI. Similarly, the Rep1-F1_BglII/Rep1-R1_BglII amplification product, comprising the $p E$ gene and the flanking intergenic regions of pScil, was digested with $B g I I I$, and the 1963 bp fragment was inserted into BglII-linearized pSRT1 to yield pMBRE. While pBSFL6 comprised the $p E$ region of $\mathrm{pSci} 2$, pMBRE contained the comparable $p E$ region of $\mathrm{pScil}$ having a $M l u \mathrm{I}$ restriction site within the $p E$ gene. To construct pMBR $\triangle E 1$, pMBRE was linearized with MluI, and recircularized by ligation after the $4 \mathrm{bp}$ cohesive ends were made blunt-ended. In this plasmid, disruption of $p E$ led to a truncated polypeptide of 97 amino acids instead of 217 in the wild-type. Similarly, in pMBR $\Delta E 2$ inserting the $19 \mathrm{bp}$ oligonucleotide duplex EBamF1/EBamR1 into the MluI site led to a truncated PE of 95 amino acids. Plasmid pNAB32H resulted from insertion of the $p 32-H A$ tagged gene inserted into pBSFL6. Each plasmid construct was confirmed by restriction mapping and sequencing the appropriate regions.

DNA isolation, Southern blot hybridization and Western immunoblotting. Spiroplasma genomic DNA was prepared from $10 \mathrm{ml}$ cultures using the Wizard genomic DNA purification kit (Promega), whereas plasmid DNA was purified from $25 \mathrm{ml}$ cultures with the Wizard SV minipreps DNA purification kit (Promega). Southern blot hybridization of spiroplasmal DNA with appropriate digoxigenin-dUTP-labelled probes has been described elsewhere (André et al., 2003). Hybridization signals were detected with antidigoxigenin-alkaline phosphatase conjugate and 2-hydroxy-3naphthoic acid-2' - phenylanilide phosphate (HNPP) as the substrate, following the supplier's instructions (Roche Diagnostics). Fluorescent signals were detected using a Fluor-S Multimager Phosphoimager (Bio-Rad). Probes specific to ScARPs, P32 and PE were generated by PCR amplification with primer pairs S235F/S235R, P32F/P32R and PEF1/PER1, respectively (Table 1). 
Table 1. Oligonucleotides and primers used in this study

\begin{tabular}{|c|c|c|c|}
\hline Name & Nucleotide sequence $\left(5^{\prime}-3^{\prime}\right)$ & Position & Accession no \\
\hline S235F & TAAACATTGATATTGCCAACCCC & $3617-3639$ & AJ969069 \\
\hline S235R & GGTTAAAGTTGCAGAATTATTATC & 3973-3996 & AJ969069 \\
\hline SR28 & ACTTTTATCGATTTTAGCAG & $114268-114287$ & AM285305 \\
\hline SR29 & ATCTTTTGCTTTAACTGTTACT & $114886-114908$ & AM285305 \\
\hline P32F & TAACGAATTAAATCATTCTAATAGC & $24852-24876$ & AJ969074 \\
\hline P32R & TAGTTCCGGCTTGCTCACCA & $24332-24351$ & AJ969074 \\
\hline PEF1 & CCCACGgaATTCTTCTATACACCTATTAAG & $11022-11051$ & AJ969070 \\
\hline PER1 & AGTATTggATcCATTGTCTTGCTACGCTGT & $12046-12075$ & AJ969070 \\
\hline Rep1-F1_BglII & ACAGTTAgAtcTGCTTGCTCTGAATAAC & $10208-10235$ & AJ969069 \\
\hline Rep1-R1_BglII & TTAATCaGaTCTGTCATAATTTCAACTCCT & $12159-12188$ & AJ969069 \\
\hline IEFR2 & CTAAATTTAAGgATCCTCATTTATTAATCATATC & $12620-12653$ & AJ969070 \\
\hline EPBg1 & AАTTCССТTAATTAACCAGATCTCCTTAATTAACCG & - & - \\
\hline $\mathrm{EPBg} 2$ & AATTCGGTTAATTAAGGAGATCTGGTTAATTAAGGG & - & - \\
\hline EBamF1 & CGCGATAGGATCCAACTAT & - & - \\
\hline EBamR1 & CGCGATAGTTGGATCCTAT & - & - \\
\hline SBamF1 & CTAGATTAGGATCCACTAAT & - & - \\
\hline SBamR1 & CTAGATTAGTGGATCCTAAT & - & - \\
\hline SojBamF1 & TCAATGGATCCATAGCTAC & - & - \\
\hline SojBamR1 & TTGAGTAGCTATGGATCCA & - & - \\
\hline
\end{tabular}

${ }^{\star}$ Bold type indicates restriction enzyme sites. Lower-case type indicates mismatched nucleotides.

Spiroplasmal proteins were separated by SDS-PAGE and further analysed by immunoblotting as described previously (Duret et al., 2003) except that the proteins reacting with the primary antibodies were visualized by using a goat anti-rabbit immunoglobulin Gperoxidase conjugate and the SuperSignal West Pico chemiluminescent substrate (Pierce).

In silico analyses. The BLAST program (Altschul et al., 1997) was used to search for homologies in general databases (http://www.ncbi.nlm.nih.gov/blast/), the mollicute dedicated database MolliGen (Barré et al., 2004), and the S. kunkelii partially sequenced genome (http:// www.genome.ou.edu/blast/spiro_blastall.html). Conserved domains were detected by CD-Search against the NCBI's conserved domain database (Marchler-Bauer \& Bryant, 2004). Global sequence alignments were accomplished using a Needleman-Wunsch algorithm implemented in the Needle program (Needleman \& Wunsch, 1970). Multiple alignments were done with T-Coffee (Notredame et al., 2000) and/or ClUSTAL W (Thompson et al., 1994). For subsequent phylogenetic analyses, poorly aligned positions and divergent regions were eliminated using the alignment curation program Gblocks (Castresana, 2000). Neighbour-joining trees based on these alignments were constructed using the MEGA 3.1 program (Kumar et al., 2004) and maximum-likelihood trees were computed with the WAG substitution model using the PhyML program (Guindon \& Gascuel, 2003). All trees were bootstrapped 100 times.

\section{RESULTS}

\section{Plasmids from S. citri GIl3 all contain CDS pE and soj}

S. citri strain GII3 carries seven plasmids, pSciA (7.8 kbp) and pSci1-6 (13-35 kbp) (Saillard et al., 2008), which share a large number of highly conserved regions and display a mosaic gene organization (Fig. 1). Most of the CDS are present on several plasmids and, reciprocally, very few of them are specific to one given plasmid. Such an exception is $p 32$, encoding a hydrophilic protein specific to pSci6 (Killiny et al., 2006). Surprisingly, most of the plasmid CDS have no orthologues in other bacterial genera, with the exceptions of $s o j, \operatorname{trs} E, \operatorname{tra} G$ and $m o b$, the naming of which indicates that they encode proteins closely related to proteins involved in partitioning (Soj/ ParA family COG1192) and transfer (TrsE, TraG and Mob) of DNA molecules. The scarp genes of pSci1-5 encode proteins sharing strong similarities with the adhesin-like protein SARP1 from S. citri BR3 (Berg et al., 2001). Plasmid pSci2 (14.4 kbp) seems to represent the 'core plasmid' as it displays a gene organization ( $p E, p F, p A, s o j$, $p B$, scarp, $p C, p D, \operatorname{trs} E, p 4, m o b)$ which is conserved in pSci1 (13 kbp) and larger plasmids pSci3 (19.3 kbp) and pSci4 (20.2 kbp) (Fig. 1). Plasmid pSci3 possesses an additional CDS $(p G)$, whereas pSci4 carries two scarp genes, two copies of $s o j$, and the additional CDS $p H$, which is absent in the other three plasmids pScil-3. In pScil, pSci5 and pSci6, the mob-like gene is disrupted. The large plasmids pSci5 and pSci6 probably result from recombination between plasmids and/or from gene duplication. Whereas pScil-3 contain a single copy of $p E$ and $s o j$, pSci4-6 have two copies of $s o j$, and multiple copies of $p E$ are present in pSci5 (2 copies) and pSci6 (4 copies). Interestingly, $p E$ and soj are the only two CDS that are conserved, uninterrupted, in all seven plasmids, pSciA and pSci1-6, suggesting that these genes may be essential for replication and maintenance of the plasmids. 


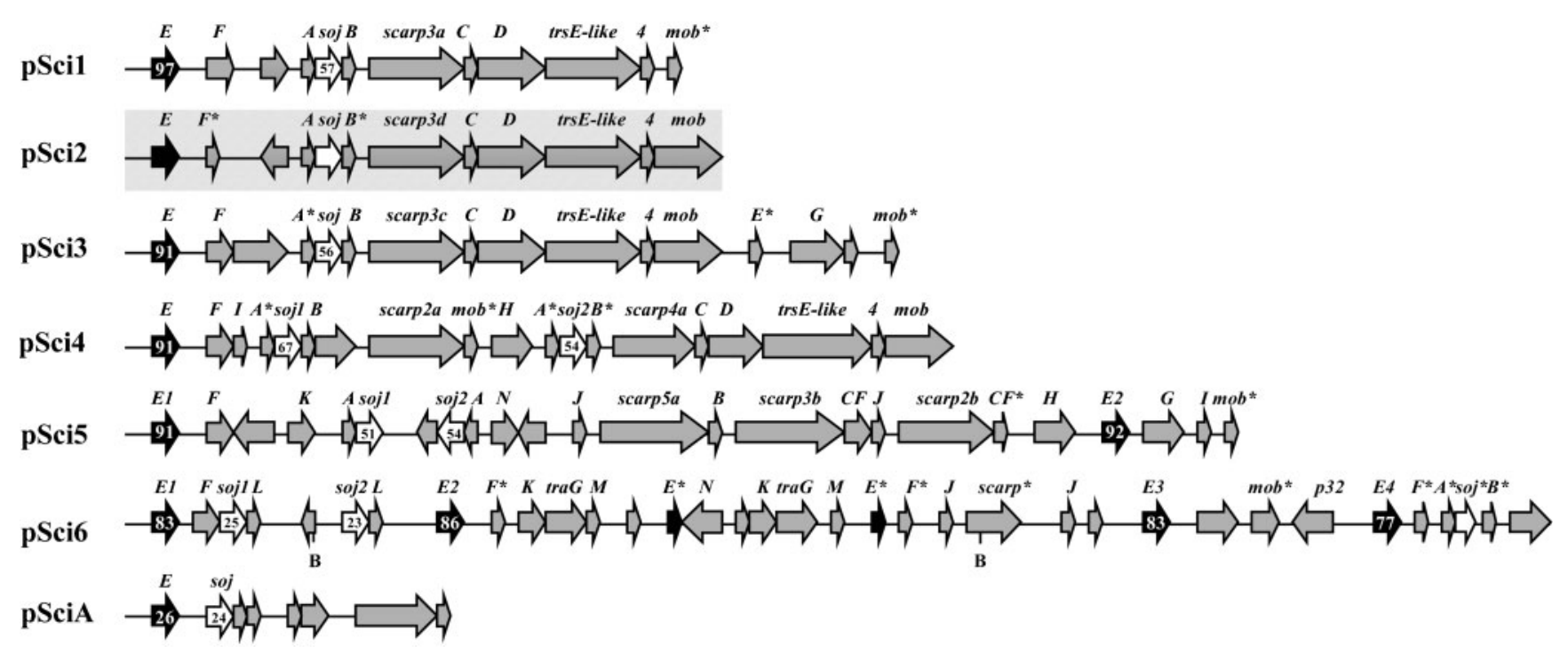

Fig. 1. Gene organization of plasmids $p S c i A$ and pSci1-6 from S. citri GII3. CDS $p E$ and soj are indicated by black and white arrows, respectively. Numbers indicate the percentages of identical amino acids shared by the $p E$ and soj protein products with their counterparts from pSci2. Conserved CDS are named ( $A$ to $N$, corresponding to $\mathrm{pA}-\mathrm{N}$ in the databases) whereas orphan CDS are not. Positions of BstBI restriction sites (B) of pSci6 are indicated. scarp, genes encoding $S$. citri adhesion-related proteins. * indicates truncated CDS. For alignment, pSciA and pSci1-6 were linearized arbitrarily regardless of the sequence numbering (GenBank accession numbers AJ966734 and AJ969069-74).

\section{Replication region of $\mathrm{pSci2}$}

Preliminary data strongly suggested that the replication region of pSci2 was located within the NsiI fragment of 8034 bp (Berho et al., 2006a). This fragment encodes seven putative polypeptides, including a Mob-like ATPase and a Soj-like protein (Fig. 2). Polypeptides PA and PE, as well as the truncated $\mathrm{PB}$ and $\mathrm{PF}$, are hypothetical proteins that have counterparts in other pSci plasmids, whereas the hypothetical polypeptide HP shares no homology with other proteins. None of these polypeptides share homology with known replication proteins. To identify the replication region of $\mathrm{pSci} 2$, various $\mathrm{pSci} 2$ derivatives were constructed by successive deletions of pSci21NT, and tested for their ability to replicate through transformation of $S$. citri 44, a strain which contains no plasmid. Plasmid constructs are described in Methods. The finding that pFL3, pFL4, pFL5, pFL6 and pFL7 all replicated in S. citri showed that the replication region was located within the 1876 bp HaelII-AclI fragment of pFL3 (Fig. 2). Interestingly, this DNA fragment comprised a single CDS, suggesting that the $p E$-encoded polypeptide might be the replication protein and that the flanking intergenic regions contained the cis-acting binding sites. In silico analyses revealed the region upstream of $p E$ to contain specific features including the imperfect repeats ATTTAATCCCCC and ATTTAACCCCC (at positions 10963 and 11084 of pSci2) and four sequences (GTTTCCATA, ATTTCCACA, TCTACCACA and TTTTCCAAA, at positions 10833, 10899, 10977 and 11268, respectively) resembling the DnaA boxes
(TTTTCCACA) of the S. citri chromosomal replication origin (oriC) (Ye et al., 1994). However, in contrast to the situation at $\operatorname{oriC}$, these sequences did not cluster within a short region. Immediately downstream of $p E$, two tandem repeated sequences of 11 nucleotides (TAACTCCCCTA), as well as an A-T rich region, were detected (Fig. 2). However, none of the six inverted repeat sequences identified in the intergenic region downstream of $p E$ (Saillard et al., 2008) was located within the $1876 \mathrm{bp}$ minimal replicon, indicating that these sequences, which putatively lead to hairpin structures, are not essential for plasmid replication. To further delineate the replication region, DNA fragments were retrieved from pFL6 by digestion or PCR amplification and inserted into ColE1 replicons by cloning in E. coli. Whereas the recombinant plasmid pBSFL6, which contained the $p E$ gene and the flanking intergenic regions, readily replicated in S. citri, plasmid pSDE1 did not, indicating that replication probably requires sequences upstream of primer PEF1.

\section{CDS E encodes the replication protein}

To further demonstrate the role of $\mathrm{PE}$ in plasmid replication, shuttle plasmid pMBRE and its $p E$-disrupted derivatives $\mathrm{pMBR} \triangle \mathrm{E} 1$ and $\mathrm{pMBR} \triangle \mathrm{E} 2$ were used to transform S. citri 44. As expected, transformation by pMBRE yielded tetracycline-resistant transformants at relatively high frequency $\left(\sim 10^{-4}\right.$ transformants c.f.u. $\left.{ }^{-1} \mu \mathrm{g}^{-1}\right)$, indicating that the plasmid replicated in these cells. The presence of the relevant plasmid in the 


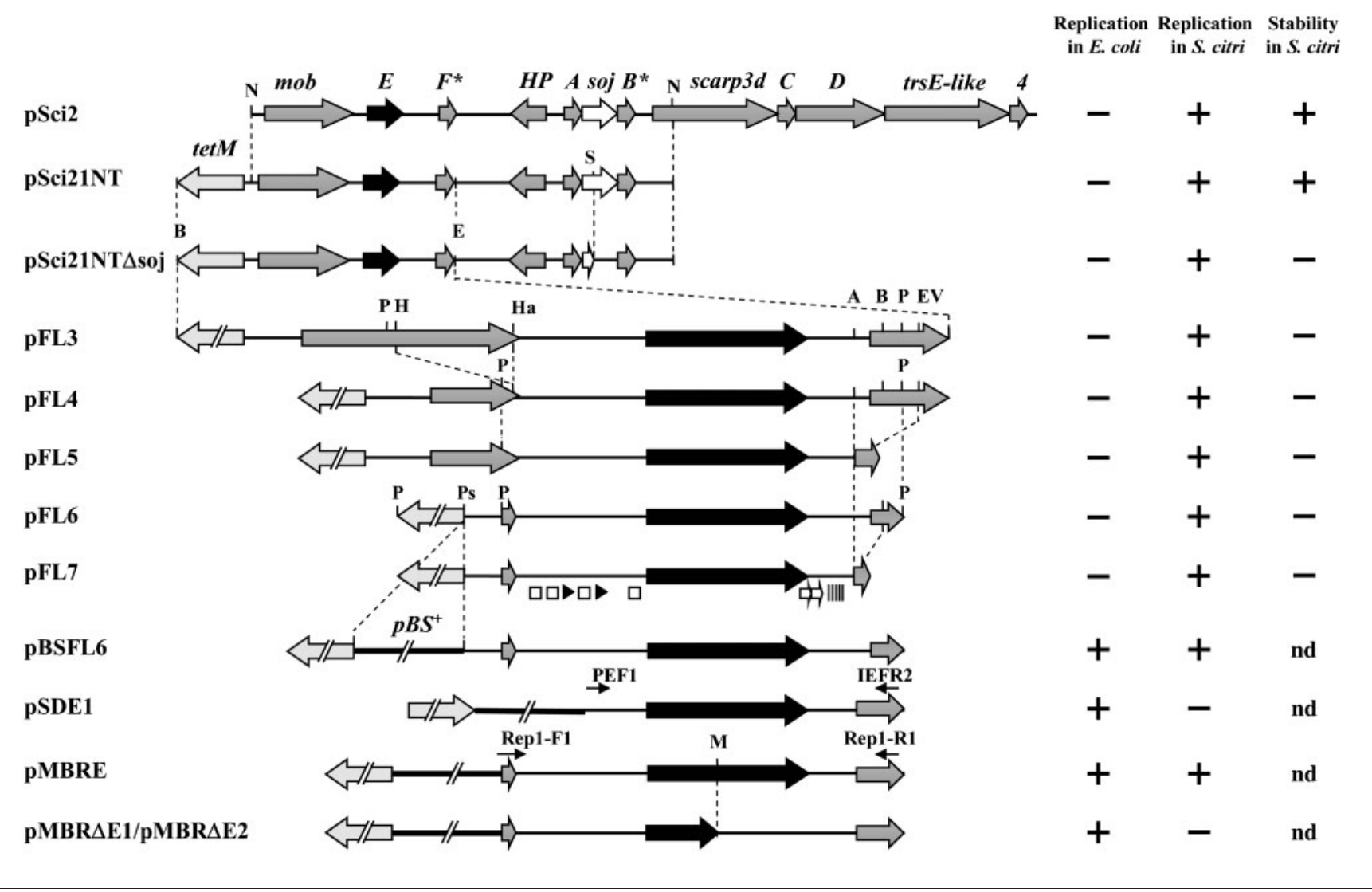

Fig. 2. Structural organization of $\mathrm{pSci} 2$ deletion derivatives, and ColE1 replicons carrying the pSci1 or pSci2 replication region. Plasmid constructs are described in Methods. Putative DnaA boxes ( $\square$ ), repeated sequences $(\nabla)$, iteron-like sequences (small white arrows), and an AT-rich region (IIII) are indicated in the minimum replicon pFL7 only. A, Acll; B, Bg/ll; E, EcoRI; EV, EcoRV; H, Hincll; Ha, Haelli; M, Mlul; N, Nsi; P, Pacl; Ps, Pstl; S, Smll; nd, not done. + and - indicate the ability or inability to replicate or to be stably maintained in the absence of selection pressure. ${ }^{*}$ indicates truncated CDS of pSci2.

spiroplasmal transformants was confirmed by PCR and Southern blot hybridization (data not shown). In contrast, no transformants were obtained through transformation with $\mathrm{pMBR} \Delta \mathrm{E} 1$ and $\mathrm{pMBR} \Delta \mathrm{E} 2$, in which the $p E$ gene was disrupted (see Methods and Fig. 2). As a control, disruption of the scarp gene in pScilNT $\Delta S$ had no effect on the ability of the plasmid to replicate.

Considering PE as the replication protein, one would expect pMBR $\Delta \mathrm{E} 1$ and $\mathrm{pMBR} \Delta \mathrm{E} 2$ to replicate in $S$. citri GII3, a strain with plasmids, from which wild-type PE was known to be expressed, as indicated by proteome analyses (unpublished data). However, transformation of S. citri GII3 by these plasmids failed repeatedly, indicating that replication of pMBR $\Delta \mathrm{E} 1$ and $\mathrm{pMBR} \Delta \mathrm{E} 2$ cannot be driven by the PE protein when provided in trans from endogenous plasmids.

Alignments of the PE proteins from pSci1-6 showed that they share strong similarities to each other, with the conserved regions being distributed all along the protein sequence. Identities ranged from $76.1 \%$ between pSci1-PE and pSci6-PE4 to $97.7 \%$ between pSci3-PE and pSci5-PE1
(Fig. 1 and Supplementary Fig. S1). The pSciA-PE was much less conserved with identities ranging from $25.2 \%$ with pSci1-PE to $28.4 \%$ with pSci6-PE1. Unexpectedly, despite the PE protein being essential for plasmid replication, no putative DNA-binding motif such as helix-turn-helix, coiled coil, zinc finger, or leucine zipper was predicted in the PE sequence. It is noteworthy that most of the PE polypeptides end with an identical Cterminus (ELDNLD), except that from pSciA and three of the four PE from pSci6, which have distinct C-termini (Supplementary Fig. S1). The autonomous replication of the $16195 \mathrm{bp}$ circularized BstBI fragment of pSci6PT (unpublished data) indicated that at least one $\mathrm{PE}$ of pSci6 (pSci6 E2 in Fig. 1) functioned as the replication protein. Whether the other three are functional or not has not yet been investigated. Studying the genetic relatedness of the S. citri GII3 proteins PEs showed that they clustered within three distinct groups (Fig. 3). The largest group consisted of PEs from pScil-5 and the PE counterparts of pBJS-O from S. citri BR3 (Joshi et al., 2005) and pSKU146 from S. kunkelii CR2-3X (Davis et al., 2005). Unexpectedly, whereas one PE (PE2) from pSci6 also fell in this group, the 


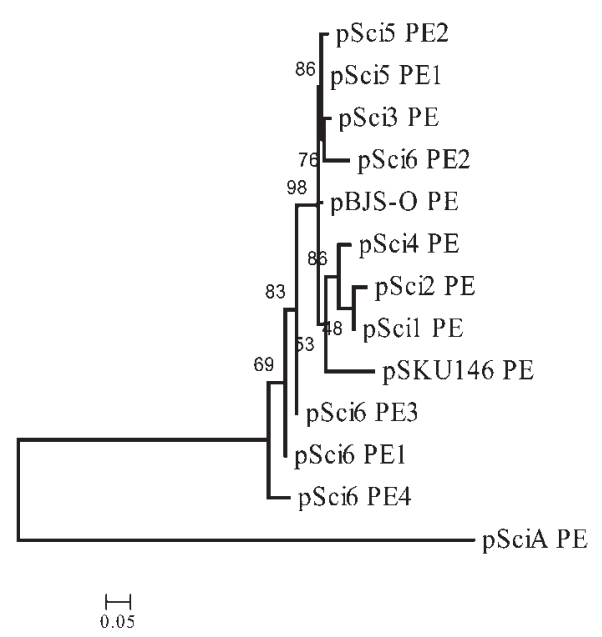

Fig. 3. Phylogenetic tree of the PE proteins from S. citri ( $p S c i A$, pSci1-6, and pBJS-O) and S. kunkelii (pSKU146) plasmids. Sequences were aligned with the T-Coffee program and analysed as described in Methods.

other three (PE1, 3 and 4) formed a distinct, heterogeneous group. Such variability is consistent with the hypothesis that, in contrast to PE2, PE1, 3 and 4 might not be functional. Whether the occurrence of multiple copies of the $p E$ gene in $\mathrm{pSci6}$ resulted from gene duplication or recombination between plasmids is unclear. Intriguingly, the pSciA PE did not cluster with any other PE proteins, suggesting that pSciA had a distinct origin. This is in agreement with the fact that, except for PE and Soj, the pSciA CDS have no counterparts in any other S. citri plasmids.

\section{Stability of pSci plasmids}

S. citri strain GII3, originally isolated in 1980, has been triply cloned and further propagated for hundreds of generations. Plasmids pSci1-6 from this strain, GII3-3X, displayed characteristic hybridization patterns when probed with a mixture of probes scarp and $p 32$ (Berho et al., 2006b). To further confirm the presence of the six plasmids in every cell, the spiroplasma strain was further subcloned twice, and the plasmid contents of 10 isolated colonies were characterized by Southern blot hybridization of total DNA. The hybridization patterns of all 10 subclones tested were identical to each other and to that of the original culture (Supplementary Fig. S2), indicating that each spiroplasma cell contained the whole set of plasmids, pSci1-6. Identical hybridization patterns were obtained with spiroplasma cultures isolated from the leafhopper vector and from the host plant after experimental transmission of GII3-3X, by injection, to its leafhopper vector (data not shown).

As indicated above, each $S$. citri plasmid contains at least one soj-like gene, encoding a polypeptide with significant similarities to proteins of the Soj/ParA, ATPase family involved in chromosome partitioning. Similarities to the chromosomal ParA of S. citri and the Soj protein of Bacillus subtilis ranged from 41.3 to $46.3 \%$ and from 41.6 to $50.8 \%$, respectively. In the plasmid-encoded Soj, COG1192 (Soj) and COG0455 (ATPases involved in chromosome partitioning) were predicted with significant probabilities (e-values ranging from $3 \times 10^{-10}$ to $1 \times 10^{-28}$ ). Like the chromosomal ParA, the pSci-encoded Soj all possessed the deviant Walker-type ATPase consensus motif with the typical A, A', and B boxes (Koonin, 1993) (Supplementary Fig. S3).

To investigate the role of Soj in $S$. citri plasmid partitioning, we assessed the stability of various pSci2 derivatives in S. citri 44 transformants. In the experiment shown in Fig. 4, S. citri 44 cells transformed with pSci21NT (containing soj) or pFL3 (lacking soj) were propagated in the absence of selection pressure. After 5, 15 and 30 passages ( 30 passages correspond to 100 generations), the plasmid contents of 10 individual clones were analysed by Southern blot hybridization. The results showed that pSci21NT was detected in each of the 10 clones tested, regardless of the passage number $(5,15$ or 30$)$. In contrast, pFL3 was lost in three clones out of ten, as early as the fifth passage. After 15 passages, pFL3 was detected in only two clones, and after 30 passages, none of the ten clones carried pFL3. The finding that, in the absence of selection pressure, pSci21NT was stably maintained for many generations whereas pFL3 was rapidly lost strongly suggested that the soj-encoded protein was indeed involved in partitioning of pSci2. In accordance with these results, plasmid loss was also noticed in spiroplasmas transformed with pSci2 derivatives pFL4, pFL5 and pFL6, all of which lack soj. However, when compared with pSci21NT these plasmids

(a)
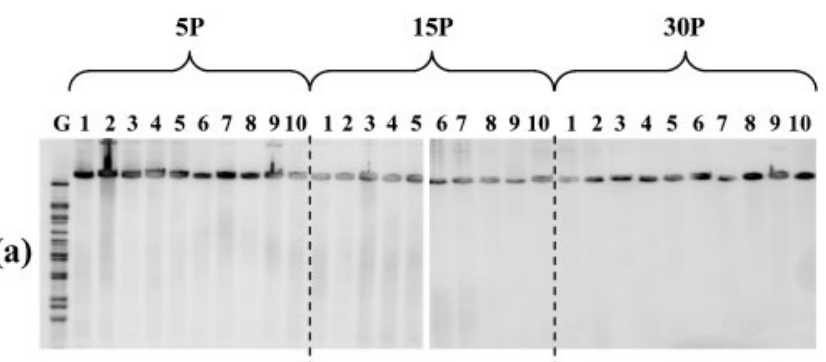

(b)

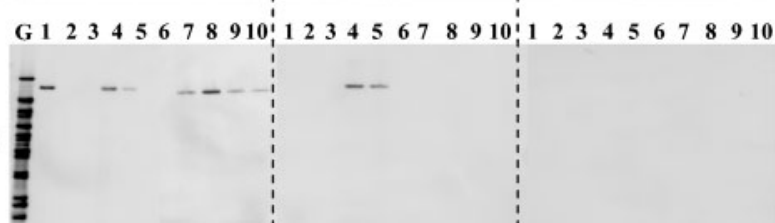

Fig. 4. Segregational stability of pSci21NT and pFL3. Southern blot hybridization of Hincll-restricted DNAs from S. citri Gll3 (lane G) and S. citri 44 transformants (lanes 1-10) with probe $p E$. Total DNAs were extracted after 5,15 and 30 passages in the absence of selection pressure. (a) pSci21NT; (b) pFL3. 
lack not only soj but also three additional CDS, the two conserved hypothetical proteins $\mathrm{PA}$ and $\mathrm{PB}$ as well as the orphan CDS HP (Fig. 2). The role of Soj was further demonstrated by evaluating the stability of pSci21NT $\Delta$ soj, a plasmid in which the soj gene was disrupted, in S. citri 44 transformants. After propagation for up to 30 passages in the absence of selection pressure, the presence of the plasmid was checked by monitoring the percentage of spiroplasma cells growing on selective (tetracycline) agar medium. As expected from the above experiment, nearly $100 \%(285$ /294) of cells from pSci21NT transformants were still tetracycline-resistant after 30 passages. In contrast, in pSci21NT $\Delta$ soj transformants, the ratio of tetracycline-resistant to total cells progressively decreased to $81 \%(515 / 638)$ at the fifth passage, $27 \%(132 / 496)$ at the 15th passage, and less than $0.2 \%$ (less than $1 / 417$ ) after 30 passages. These results clearly indicated that the soj gene product is involved in the stability of pSci plasmids.

\section{Phylogeny of plasmid Soj proteins}

Sequence alignments of predicted Soj proteins (Supplementary Fig. S3) revealed that those from plasmids pScil-5 were more closely related to each other (identities ranging from 50.4 to $82.9 \%$ ) than to Soj from pSci6 (22.4 to $28.3 \%$ identity), and that those from pScil-6 shared a low percentage ( 24 to $29.2 \%$ ) of identical amino acids with pSciA. The bootstrapped phylogenetic tree (Fig. 5) indicates that plasmid-encoded Soj were distinct from the chromosomal Soj/ParA and clustered in two separate groups: Soj from pSci1-5 (S. citri GII3) and pBJS-O ( $S$. citri BR3) in one group, and Soj from pSciA and pSci6 ( $S$. citri GII3), and pSKU146 (S. kunkelii E275) in the other, suggesting that these groups had evolved separately and

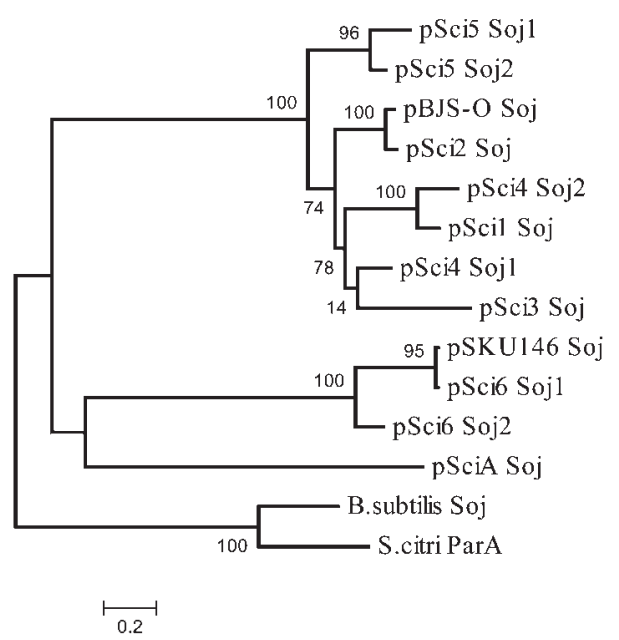

Fig. 5. Phylogenetic relationships of plasmid Soj proteins from $S$. citri (pSciA, pSci1-6 and pBJS-O) and S. kunkelii (pSKU146), and chromosomal Soj proteins from $S$. citri and $B$. subtilis. Sequences were aligned with the T-Coffee program and analysed as described inMethods. disjointedly from the chromosomal ParA. In an effort to understand the origin of these plasmids, phylogenetic analyses of spiroplasma Soj proteins were extended to a set of representative ParA homologues (Gerdes et al., 2000) including the 23 annotated ParA homologues from mollicute genomes (http://cbi.labri.fr/outils/molligen/). The phylogenetic tree showed that, as in many bacteria (McLeod et al., 2006), the chromosomally encoded ParA proteins of spiroplasmas had phylogenies congruent with those of their hosts. In contrast, the plasmid-encoded Soj/ ParA proteins were more diverse and their clustering did not follow the organismal phylogeny (Supplementary Fig. S4). When restricted to the mollicutes and several other firmicutes, these analyses identified four major clusters supported by strong bootstrap values (Supplementary Fig. S5). One coherent cluster was made from the S. citri chromosomal ParA and other chromosomal ParA proteins of firmicutes (except those of mycoplasmas). A second cluster consisted of the mycoplasmal chromosomeencoded ParA/Soj proteins, whose genes are located in the vicinity of the chromosome replication origin. These proteins are clearly distinct from ParA/Soj proteins of other firmicutes and the spiroplasmas in particular. The third cluster comprised plasmid-encoded Soj proteins from $S$. citri pScil-5 and pBJS-O; the fourth cluster consisted of Soj proteins from S. citri pSciA and pSci6, S. kunkelii pSKU146, and chromosomal Soj proteins that are encoded by putative or demonstrated mobile elements of mycoplasmas (Marenda et al., 2006; Sirand-Pugnet et al., 2007).

\section{Distribution and host-range of S. citri pSci plasmids}

Previous studies showed that, in contrast to GII3, various S. citri strains did not contain plasmids pScil-6, as revealed by the failure of genomic DNAs to hybridize with scarp and p32 probes (Berho et al., 2006b). To investigate the occurrence of PE replicating plasmids in spiroplasmas further, genomic DNAs from various strains of $S$. citri and other spiroplasma species were hybridized with probes scarp and $p E$ (Fig. 6, Table 2). Both scarp and $p E$ hybridization signals were detected in strains GII3, Corse, Palmyre, Hinckley, IP85 and Israel. In contrast, no hybridization signal was detected in ASP-1, R8A2 and 44. Detection of $p E$ but not scarp sequences in strain Alcanar 254 is consistent with the fact that this strain carries a single plasmid nearly identical to pSci6 (unpublished data), which contains no scarp genes. Interestingly, $p E$-hybridizing signals were also detected in the plant-pathogenic spiroplasmas S. kunkelii E275 (subgroup I-3) and S. phoeniceum P40 (subgroup I-8), indicating that PE replicons were not restricted to the species $S$. citri, i.e. subgroup I-1 of the spiroplasmal classification (Williamson et al., 1998). In addition, the $p E$ probe was found to hybridize with genomic DNAs from the bee pathogen Spiroplasma melliferum (subgroup I-2) strains BC3, G1 and AS576, the rabbit tick spiroplasma 277F (I-4), the plant bug spiroplasma sp. LB-12 (I-5), and the plant surface 


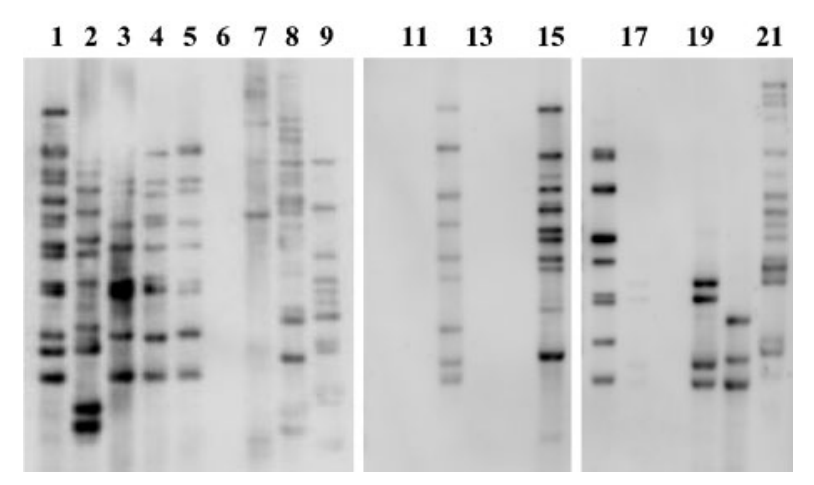

Fig. 6. Southern blot hybridization of Hincll-restricted DNAs from various spiroplasmas with the $p E$ probe. DNAs were from $S$. citri GII3, Palmyre, Israel, Hinckley, IP85 and R8A2 (lanes 1-6), ASP-1 and 44 (lanes 13 and 14), M4 and MHcl2 (lanes 15 and 16), Corse (lane 21), S. melliferum BC3 and G1 (lanes 19 and 20), S. kunkelii E275 (lane 7), Spiroplasma sp. 277F and LB12 (lanes 8 and 12), S. phoeniceum P40 (lane 9), S. floricola 23.6 (lane 10), S. apis B31 (lane 11), S. mirum SMCA (lane 17) and S. ixodetis Y32 (lane 18).

Spiroplasma sp. N525 (I-7) but not with DNAs from strains B13 and B31 of the bee pathogen Spiroplasma apis (group IV) and strain 23.6 of the plant surface Spiroplasma floricola (group IV). From these data, the PE replicons appear to be restricted to species of group I spiroplasmas. Unlike pSci1-5 from S. citri GII3, these replicons do not necessarily contain conserved scarp genes. Similarly to $S$. citri Alcanar 254, PE replicons from S. melliferum did not hybridize with the scarp probe.

The occurrence of PE replicons in many spiroplasma species suggested that these plasmids might have a broad host-range. Therefore we explored the possibility of transforming various strains of $S$. citri as well as other spiroplasma species with pSci21NT and pFL6, two derivatives of pSci2 from $S$. citri GII3. Both plasmids were introduced successfully and replicated in all S. citri strains tested (GII3, ASP-1, Alcanar 254, R8A2 and 44), regardless of the strains' natural plasmid contents. Transformation frequencies ranged from $10^{-5}$ to $10^{-3}$ transformants c.f.u. $^{-1}$ ( $\mu$ g plasmid) $)^{-1}$. In particular, it is noteworthy that strain R8A2, which could only be transformed at extremely low efficiency (less than $10^{-8}$ transformants c.f.u. ${ }^{-1} \mu \mathrm{g}^{-1}$ ) by oriC plasmids (Renaudin et al., 1995) was repeatedly transformed by pSci21NT and pFL6 at frequencies close to $10^{-5}$ transformants c.f.u. ${ }^{-1} \mu \mathrm{g}^{-1}$. Interestingly, transformation of S. kunkelii E275 and S. phoeniceum P40 by pSci21NT, pFL6, and its shuttle derivative pBSFL6 also yielded tetracycline-resistant transformants at frequencies of $10^{-5}-10^{-4}$ transformants c.f.u. ${ }^{-1} \mu \mathrm{g}^{-1}$. The possibility that these tetracycline-resistant cells could be spontaneous mutants or contaminants was excluded by showing that they did contain the relevant plasmid, by PCR and Southern blot hybridization, and by confirming the spiroplasma species through PCR-RFLP analysis of the spiralin gene (Methods).

\section{pSci-derived plasmids as gene vectors}

To demonstrate the usefulness of pSci-derived plasmids as gene vectors, the plasmid construct pNAB32H, in which the $p 32$ gene fused to a HA tag was inserted into the shuttle plasmid pBSFL6, was introduced into S. kunkelii E275 by electrotransformation. The presence of $\mathrm{pNAB} 32 \mathrm{H}$ in the spiroplasmal transformants was confirmed by PCR and Southern blot hybridizations (data not shown). In the experiment shown in Fig. 7, total proteins were probed by Western immunoblotting with P32- and HA-specific, polyclonal antibodies (Fig. 7a and b, respectively). Cells from S. citri GII3 and S. kunkelii E275 transformed by pScilNT were used as controls. As expected, P32 was detected in S. citri GII3 (Fig. 7a, lane 1) but not in untransformed S. kunkelii (lane 2) or in S. kunkelii transformed with pScilNT (lane 6). In contrast, P32related proteins were detected in S. kunkelii cells transformed by pNAB32H, carrying the $p 32-H A$ fusion gene (lanes 3 and 4), or pSci6PT containing the wild-type $p 32$ gene (lane 5). As expected, the HA-tagged protein was clearly detected in pNAB32H-transformed cells, indicating that the fusion protein was expressed from the recombinant plasmid in S. kunkelii E275 (Fig. 7b, lanes 3 and 4). In addition, the relative intensities of the P32 detection signals were consistent with an expression level of the P32-HA fusion protein from $\mathrm{pNAB} 32 \mathrm{H}$ similar to that of the wildtype P32 encoded by pSci6 in S. citri GII3.

\section{DISCUSSION}

\section{Replication protein PE}

The occurrence of highly conserved regions in the plasmids from S. citri GII3 suggests that they have a common origin. Except for $s o j, \operatorname{traG}$, $\operatorname{trs} E$ and $m o b$, most of the plasmid genes encode hypothetical proteins with no counterparts in bacteria other than spiroplasmas. Moreover, homology searches failed to identify a putative replication protein, indicating that these plasmids probably represent a new plasmid family. In particular, they do not share any homology with the phytoplasma plasmids that encode putative replication proteins (Rep) having the conserved motifs associated with the rolling circle mechanism of replication (Oshima et al., 2001; Tran-Nguyen \& Gibb, 2006). S. citri plasmids pSciA and pScil-6 all possess genes soj and $p E$, which are also conserved in plasmids pBJS-O from S. citri BR3 (Joshi et al., 2005) and pSKU146 from S. kunkelii CR2-3X (Davis et al., 2005). In this study, we showed that $p E$ is essential and the only plasmid-encoded protein required for plasmid replication. The finding that inactivation of $p E$ by a single $4 \mathrm{bp}$ insertion prevented replication clearly indicates that the polypeptide, rather than the nucleotide sequence, is required. The fact that the 
Table 2. Distribution of scarp and $p E$ sequences among various spiroplasma strains

\begin{tabular}{|c|c|c|c|c|c|}
\hline \multirow[t]{2}{*}{ Group } & \multirow[t]{2}{*}{ Species } & \multirow[t]{2}{*}{ Strains ${ }^{\star}$} & \multirow[t]{2}{*}{ Habitat } & \multicolumn{2}{|c|}{ Probe $\dagger$} \\
\hline & & & & scarp & $p E$ \\
\hline \multirow[t]{13}{*}{ I-1 } & S. citri & ASP-1 & Phloem/leafhopper & - & - \\
\hline & & C189 & & ND & - \\
\hline & & Corse & & + & + \\
\hline & & Alcanar 254 & & - & + \\
\hline & & GII3 & & + & + \\
\hline & & Hinckley & & + & + \\
\hline & & Israel & & + & + \\
\hline & & IP85 & & + & + \\
\hline & & MHcl2 & & ND & + \\
\hline & & M4 & & $\mathrm{ND}$ & + \\
\hline & & Palmyre & & + & + \\
\hline & & $\mathrm{R} 8 \mathrm{~A} 2$ & & - & - \\
\hline & & 44 & & - & - \\
\hline \multirow[t]{3}{*}{$\mathrm{I}-2$} & S. melliferum & AS576 & Honey bee & - & + \\
\hline & & BC3 & & - & + \\
\hline & & G1 & & - & + \\
\hline $\mathrm{I}-3$ & S. kunkelii & E275 & Phloem/leafhopper & + & + \\
\hline $\mathrm{I}-4$ & Spiroplasma sp. & $277 \mathrm{~F}$ & Rabbit tick & + & + \\
\hline $\mathrm{I}-5$ & Spiroplasma sp. & LB-12 & Plant bug & - & + \\
\hline I-6 & S. insolitum & M55 & Flower surface & - & - \\
\hline $\mathrm{I}-7$ & Spiroplasma sp. & N525 & Plant surface & - & + \\
\hline $\mathrm{I}-8$ & S. phoeniceum & $\mathrm{P} 40$ & Phloem/leafhopper & + & + \\
\hline III & S. floricola & 23.6 & Plant surface & - & - \\
\hline \multirow[t]{2}{*}{ IV } & S. apis & B13 & Honey bee & - & - \\
\hline & & B31 & & - & - \\
\hline V & S. mirum & SMCA & Rabbit tick & ND & - \\
\hline VI & S. ixodetis & Y32 & Ixodid tick & ND & - \\
\hline XV & Spiroplasma sp. & $\mathrm{I}-25$ & Leafhopper & - & - \\
\hline XXIII & S. gladiatoris & TG-1 & Horse fly & - & - \\
\hline
\end{tabular}

*The references for spiroplasma strains are given in Supplementary Table S1.

$\dagger+$ and - indicate positive and negative hybridization under standard stringent conditions. ND, Not done.

(a)

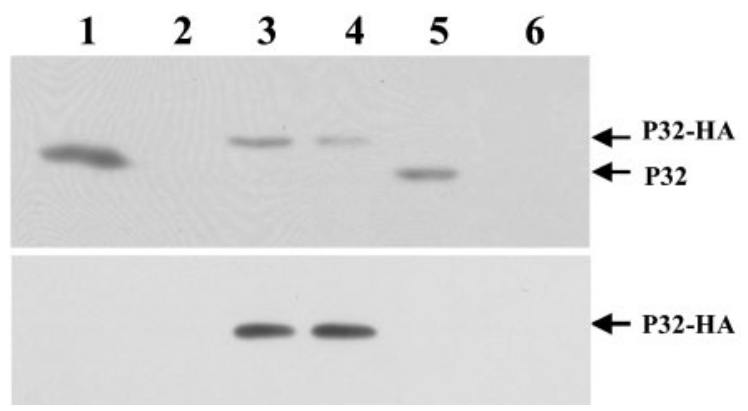

Fig. 7. Western immunoblotting of total proteins from S. citri, $S$. kunkelii and S. kunkelii transformants with P32- (a) and HA- (b) specific polyclonal antibodies. Lanes: $1, S$. citri Gll3; 2-6, S. kunkelii E275 wild-type strain (lane 2), transformed with pNAB32H (lanes 3 and 4), pSci6PT (lane 5) and pSci1NT (lane $6)$. $p E$-disrupted plasmids failed to replicate in S. citri GII3 (a strain that produces PE from endogenous plasmids) suggests that $\mathrm{PE}$, unlike other replication initiator proteins (Emond et al., 2001) might be a cis-acting protein, unable to support replication when provided in trans. In this experiment, however, the hypotheses of a retro-control system specific for $S$. citri GII3, or incompatibility between plasmids having identical replication regions, cannot be excluded (Bouet et al., 2007). Therefore, complementation of the mutation carried by the $p E$-disrupted plasmids in $S$. citri 44 will be required to definitely establish whether or not $\mathrm{PE}$ is a cis-acting protein.

Although the PE protein was found to be essential for replication, it lacks the leucine zipper and helix-turn-helix motifs found in many Rep proteins (Del Solar et al., 1998). The lack of sequence and/or structural similarity between $\mathrm{PE}$ and known replication proteins suggests that replication of spiroplasma plasmids pSci involves a distinctive mechanism. Circular bacterial plasmids use two modes of 
DNA replication known as rolling circle (RCR) and theta. RCR plasmids are generally recognized by their small size (less than $12 \mathrm{kbp}$ ), their high copy number, the generation of single-stranded intermediates, and the presence of specific functional features comprising a rep gene, encoding the replication initiator protein, and the replication origin sequences (Khan, 2005). None of these typical features of RCR plasmids apply to pSci plasmids from S. citri GII3 (Saillard et al., 2008), suggesting that pSci plasmids replicate through a theta mechanism. The presence of four putative DnaA boxes and an AT-rich region upstream of $p E$ is consistent with this hypothesis. Also, the $11 \mathrm{bp}$ tandem repeated sequences separated by $9 \mathrm{bp}$ and located immediately downstream of $p E$ might represent iterons, i.e. binding sites for the replication initiator protein. Interaction of the replication protein with its cognate iteron repeat is an important determinant of plasmid incompatibility (Bouet et al., 2007). Obviously more work is needed to determine whether or not these sequences that are strictly conserved in plasmids pScil-6 and pBJS-O of $S$. citri and pSKU146 of S. kunkelii are the binding site of the replication protein PE.

\section{Partitioning protein Soj}

In bacteria, active segregation of low-copy-number plasmids into daughter cells relies on plasmid-encoded active partitioning (par) systems. In S. citri, the fact that pScil-6 were stably maintained both in vitro and in vivo indicates that, in spite of highly conserved sequences, they exhibit no incompatibility with each other and hence suggests that each plasmid has its own partitioning system. The finding that, provided they carry a functional soj gene, the pSci2derived plasmids are stably maintained in the absence of selection pressure indicates that $S$. citri plasmids possess an active partition system involving the Soj protein. In general, the par locus encodes two trans-acting proteins expressed from an operon and one or more cis-acting centromere-like sites (Bouet et al., 2007; Ebersbach \& Gerdes, 2005). The par loci are divided into two main groups depending on the type of ParA ATPase encoded by the first gene of the $p a r A / B$ operon. Type I loci encode Walker box ATPases and type II loci encode actin-like ATPases. The type I systems can be further divided into type Ia and type Ib based on the similarities and sizes of the Par proteins, the localization of the partition site, and the mechanism of the transcriptional regulation (Gerdes et al., 2000). S. citri pSci plasmids have soj genes predicted to encode ParA superfamily ATPases. These ParA homologues possess the deviant Walker-type ATPase motif of the type I plasmid partitioning system (Koonin, 1993) and the genetic organization of soj loci is more reminiscent of type Ib. The pSci-encoded Soj proteins have reduced sizes (255260 residues) and lack the $\mathrm{N}$-terminal extension containing a DNA-binding domain, usually present in type Ia. Considering that mollicutes are phylogenetically related to Gram-positive bacteria (Weisburg et al., 1989), this is in agreement with the fact that type Ia loci have only been reported in plasmids from Gram-negative bacteria, whereas loci of type Ib have been described in both Gram-negative and Gram-positive bacteria (Gerdes et al., 2000). The hypothesis that CDS such as $p B$ located immediately downstream of soj in pSci2 could encode a ParB-like component cannot be excluded as these components frequently exhibit no conserved sequences (Ebersbach \& Gerdes, 2005). Phylogenetic analyses revealed that Soj proteins from spiroplasma plasmids clustered within two distinct groups that are clearly unrelated to spiroplasma chromosomal ParA/Soj (see Supplementary Fig. S4). Clustering of Soj from S. citri pSciA and pSci6 and S. kunkelii pSKU146 with those of the mycoplasmal mobile elements is consistent with previous observations that the arrangement of three CDS of pSKU146 paralleled that of their counterparts in the integrated conjugative element (ICE) of Mycoplasma fermentans (Calcutt et al., 2002; Davis et al., 2005), and suggests that spiroplasma plasmids and mycoplasma ICEs might have a common ancestor. It is noteworthy that, in contrast to spiroplasmas, most mycoplasmas do not possess parA/soj genes (Livny et al., 2007), and that mycoplasmas having parA/soj-like sequences all belong to the 'pneumoniae' phylogenetic group. However, the absence of parB and pars equivalents in these mycoplasmas raises the question of whether the mycoplasmal ParA function as chromosome partitioning proteins.

\section{Distribution of PE replicons}

The PE replicons were found to be widely distributed in group I spiroplasmas, including the three plant-pathogenic spiroplasmas S. citri, S. kunkelii and S. phoeniceum. In S. citri, however, strains R8A2 and 44 do not contain plasmids pSciA and pScil-6 (Berho et al., 2006b). In contrast, ASP-1 is known to carry plasmid pIJ2000 (Archer et al., 1981), highly similar if not identical to pSciA. In this case, the lack of hybridization signal probably resulted from the fact that $p E$ sequences are poorly conserved in $\mathrm{pSciA}$ (Supplementary Fig. S1). Therefore, in our experiments, the failure to hybridize with the $p E$ probe does not exclude the presence of pSciA-related plasmids. In S. phoeniceum, both scarp and $p E$ probes were found to hybridize with total DNA from $S$. phoeniceum $\mathrm{P} 40$, indicating the presence of $\mathrm{PE}$ replicons in this strain. For unknown reasons, these data do not fit with those of Joshi et al. (2005) showing that undigested plasmid preparations from $S$. phoeniceum did not hybridize with the whole $\mathrm{pBJS-O}$ probe.

\section{Expanding the genetic toolbox of spiroplasmas}

Limited cloning tools are available for the genetic modification of S. citri. Artificial oriC plasmids have been used as vectors to complement mutants (Gaurivaud et al., 2000; Jacob et al., 1997). However, due to incompatibility with the chromosomal oriC, the spiroplasmal transformants have a reduced growth rate and the plasmids are unstable, as they tend to integrate into the host chromosome. In addition, transformation frequencies of 
S. citri by oriC plasmids are relatively low, and some $S$. citri strains cannot be transformed consistently (Renaudin, 2002; Renaudin \& Lartigue, 2005). Characterizing the replication and stability regions of $\mathrm{pSci} 2$ proved the $S$. citri plasmids and their shuttle derivatives to hold considerable advantages for the development of new vectors: (i) they transform the various $S$. citri strains tested at relatively high frequencies $\left(10^{-4}-10^{-3}\right.$ transformants c.f.u. $\left.{ }^{-1} \mu \mathrm{g}^{-1}\right)$, (ii) the doubling times of the transformants are not significantly affected as compared with the wild-type, (iii) according to the demand they are either stably maintained or not, depending on the presence of $s o j$, and never integrate into the chromosome, and (iv) their host range is not restricted to $S$. citri. Indeed, they were shown to replicate in S. phoeniceum P40 and S. kunkelii E275, in which expression of the foreign protein P32-HA was demonstrated. To our knowledge this is the first report of transformation and expression of foreign genes in plantpathogenic mollicutes other than S. citri.

In pathogenic bacteria, plasmids are usually considered as being non-essential genetic elements that confer a selective advantage under specific conditions (Stewart et al., 2005; Vivian et al., 2001). Whether plasmids are required for $S$. citri survival in nature is unknown. Nevertheless, plasmidencoded determinants have been tentatively associated with insect transmission (Berg et al., 2001; Berho et al., 2006a; Killiny et al., 2006). In S. citri GII3, $\sim 10$ copies of each plasmid co-exist within the same cell. Transformation of $S$. citri 44 by extrachromosomal DNA from S. citri GII3 also revealed that many transformants contained more than one plasmid (Berho et al., 2006a). Therefore, the compatibility of the S. citri plasmids would permit the design of experiments in which two distinct plasmids must be stably maintained in the same cell. Conversely, from the preliminary observation that transformation of S. citri GII3 by selectable pSci2 derivatives led to rapid loss of the wild-type pSci2, incompatibility of identical replication regions would provide a means to displace natural plasmids by their mutated/deleted derivatives and hence to investigate the biological function of plasmid-encoded determinants.

\section{ACKNOWLEDGEMENTS}

We are grateful to P. Sirand-Pugnet for helpful discussions on phylogenetic studies. We thank F. Labroussaa for his participation in constructing pSci derivatives and S. Richard for characterizing the plasmid content of S. citri Alcanar 254. This work was funded by INRA and the Université Victor Segalen Bordeaux2. Support for M. B. was provided by the Ministère de l'Enseignement Supérieur et de la Recherche.

\section{REFERENCES}

Altschul, S. F., Madden, T. L., Schaffer, A. A., Zhang, J. H., Zhang, Z., Miller, W. \& Lipman, D. J. (1997). Gapped BLAST and PSI-BLAST: a new generation of protein database search programs. Nucleic Acids Res 25, 3389-3402.
André, A., Maccheroni, W., Doignon, F., Garnier, M. \& Renaudin, J. (2003). Glucose and trehalose PTS permeases of Spiroplasma citri probably share a single IIA domain, enabling the spiroplasma to adapt quickly to carbohydrate changes in its environment. Microbiology 149, 2687-2696.

André, A., Maucourt, M., Moing, A., Rolin, D. \& Renaudin, J. (2005). Sugar import and phytopathogenicity of Spiroplasma citri: glucose and fructose play distinct roles. Mol Plant Microbe Interact 18, 33-42.

Archer, D. B., Best, J. \& Barber, C. (1981). Isolation and restriction mapping of a spiroplasma plasmid. J Gen Microbiol 126, 511-514.

Barré, A., de Daruvar, A. \& Blanchard, A. (2004). MolliGen, a database dedicated to the comparative genomics of Mollicutes. Nucleic Acids Res 32, D307-D310.

Berg, M., Melcher, U. \& Fletcher, J. (2001). Characterization of Spiroplasma citri adhesion related protein SARP1, which contains a domain of a novel family designated sarpin. Gene 275, 57-64.

Berho, N., Duret, S., Danet, J. L. \& Renaudin, J. (2006a). Plasmid pSci6 from Spiroplasma citri GII-3 confers insect transmissibility to the non-transmissible S. citri strain 44. Microbiology 152, 2703-2716.

Berho, N., Duret, S. \& Renaudin, J. (2006b). Absence of plasmids encoding adhesion-related proteins in non-insect-transmissible strains of Spiroplasma citri. Microbiology 152, 873-886.

Bouet, J. Y., Nordstrom, K. \& Lane, D. (2007). Plasmid partition and incompatibility - the focus shifts. Mol Microbiol 65, 1405-1414.

Bové, J. M., Carle, P., Garnier, M., Laigret, F., Renaudin, J. \& Saillard, C. (1989). Molecular and cellular biology of spiroplasmas. In The Mycoplasma, vol. 5, pp. 243-364. Edited by R. F. Whitcomb \& J. G. Tully. New York: Academic Press.

Bové, J. M., Renaudin, J., Saillard, C., Foissac, X. \& Garnier, M. (2003). Spiroplasma citri, a plant pathogenic mollicute: relationships with its two hosts, the plant and the leafhopper vector. Annu Rev Phytopathol 41, 483-500.

Calcutt, M. J., Lewis, M. S. \& Wise, K. S. (2002). Molecular and genetic analysis of IECF, an integrative conjugative element that is present in the chromosome of Mycoplasma fermentans PG18. J Bacteriol 184, 6929-6941.

Castresana, J. (2000). Selection of conserved blocks from multiple alignments for their use in phylogenetic analysis. Mol Biol Evol 17, 540-552.

Davis, R. E., Dally, E. L., Jomantiene, R., Zhao, Y., Roe, B., Lin, S. \& Shao, J. (2005). Cryptic plasmid pSKU146 from the wall-less plant pathogen Spiroplasma kunkelii encodes an adhesin and components of a type IV translocation-related conjugation system. Plasmid 53, 179-190.

Del Solar, G., Giraldo, R., Ruiz-Echevarria, M. J., Espinoza, M. \& Diaz-Orejas, R. (1998). Replication and control of circular bacterial plasmids. Microbiol Mol Biol Rev 62, 434-464.

Duret, S., Berho, N., Danet, J. L., Garnier, M. \& Renaudin, J. (2003). Spiralin is not essential for helicity, motility, or pathogenicity but is required for efficient transmission of Spiroplasma citri by its leafhopper vector Circulifer haematoceps. Appl Environ Microbiol 69, 6225-6234.

Ebersbach, G. \& Gerdes, K. (2005). Plasmid segregation mechanisms. Annu Rev Genet 39, 453-479.

Emond, E., Lavallée, R., Drolet, G., Moineau, S. \& Lapointe, G. (2001). Molecular characterization of a theta replication plasmid and its use for development of a two-component food-grade cloning system for Lactococcus lactis. Appl Environ Microbiol 67, 1700-1709.

Fletcher, J., Schultz, G. A., Davis, R. E., Eastman, C. E. \& Goodman, R. M. (1981). Brittle root disease of horseradish: evidence for an etiological role of Spiroplasma citri. Phytopathology 71, 1073-1080.

Foissac, X., Danet, J. L., Saillard, C., Whitcomb, R. F. \& Bové, J. M. (1996). Experimental infections of plants by spiroplasmas. In 
Molecular and Diagnostic Procedures in Mycoplasmology, vol. 2, pp. 385-389. Edited by S. Razin \& J. G. Tully. New York: Academic Press.

Foissac, X., Saillard, C. \& Bové, J. M. (1997). Random insertion of transposon Tn 4001 in the genome of Spiroplasma citri strain GII3. Plasmid 37, 80-86.

Gasparich, G. E., Hackett, K. J., Clark, E. A., Renaudin, J. \& Whitcomb, R. F. (1993). Occurrence of extrachromosomal deoxyribonucleic acids in spiroplasmas associated with plants, insects, and ticks. Plasmid 29, 81-93.

Gaurivaud, P., Danet, J. L., Laigret, F., Garnier, M. \& Bové, J. M. (2000). Fructose utilization and phytopathogenicity of Spiroplasma citri. Mol Plant Microbe Interact 13, 1145-1155.

Gerdes, K., Moller-Jensen, J. \& Jensen, R. B. (2000). Plasmid and chromosome partitioning: surprises from phylogeny. Mol Microbiol 37, 455-466.

Guindon, S. \& Gascuel, O. (2003). A simple, fast, and accurate algorithm to estimate large phylogenies by maximum likelihood. Syst Biol 52, 696-704.

Hosseini Pour, A. (2000). Determination of some molecular and cellular characteristics of Spiroplasma citri, the causal agent of citrus stubborn disease in Kerman, Fars and Mazadaran provinces. $\mathrm{PhD}$ thesis, Tarbiat Modares University, Tehran.

Jacob, C., Nouzieres, F., Duret, S., Bové, J. M. \& Renaudin, J. (1997). Isolation, characterization, and complementation of a motility mutant of Spiroplasma citri. J Bacteriol 179, 4802-4810.

Joshi, B. D., Berg, M., Rogers, J., Fletcher, J. \& Melcher, U. (2005). Sequence comparisons of plasmids pBJS-O of Spiroplasma citri and pSKU146 of S. kunkelii: implications for plasmid evolution. BMC Genomics 6, 175-185.

Khan, S. A. (2005). Plasmid rolling-circle replication: highlights of two decades of research. Plasmid 53, 126-136.

Killiny, N., Castroviejo, M. \& Saillard, C. (2005). Spiroplasma citri spiralin acts in vitro as a lectin binding to glycoproteins from its insect vector Circulifer haematoceps. Phytopathology 95, 541-548.

Killiny, N., Batailler, B., Foissac, X. \& Saillard, C. (2006). Identification of a Spiroplasma citri hydrophilic protein associated with insect transmissibility. Microbiology 152, 1221-1230.

Koonin, E. V. (1993). A superfamily of ATPases with diverse functions containing either classical or deviant ATP-binding motif. J Mol Biol 229, 1165-1174.

Kumar, S., Tamura, K. \& Nei, M. (2004). MEGA3: integrated software for Molecular Evolutionary Genetics Analysis and sequence alignment. Brief Bioinform 5, 150-163.

Lartigue, C., Duret, S., Garnier, M. \& Renaudin, J. (2002). New plasmid vectors for specific gene targeting in Spiroplasma citri. Plasmid 48, 149-159.

Livny, J., Yamaichi, Y. \& Waldor, M. K. (2007). Distribution of centromere-like parS sites in bacteria: insights from comparative genomics. J Bacteriol 189, 8693-8703.

Marchler-Bauer, A. \& Bryant, S. H. (2004). CD-Search: protein domain annotations on the fly. Nucleic Acids Res 32, W327-W331.

Marenda, M., Barbe, V., Gourgues, G., Mangenot, S., Sagne, E. \& Citti, C. (2006). A new integrative conjugative element occurs in Mycoplasma agalactiae as chromosomal and free circular forms. J Bacteriol 188, 4137-4141.

McLeod, M. P., Warren, R. L., Hsiao, W. W., Araki, N., Myhre, M., Fernandes, C., Miyazawa, D., Wong, W., Lillquist, A. L. \& other authors (2006). The complete genome of Rhodococcus sp. RHA1 provides insights into a catabolic powerhouse. Proc Natl Acad Sci U S A $103,15582-15587$.
Mouchès, C., Barroso, G. \& Bové, J. M. (1983a). Characterization and molecular cloning in Escherichia coli of a plasmid from the mollicute Spiroplasma citri. J Bacteriol 156, 952-955.

Needleman, S. B. \& Wunsch, C. D. (1970). A general method applicable to the search for similarities in the amino acid sequence of two proteins. J Mol Biol 48, 443-453.

Notredame, C., Higgins, D. G. \& Heringa, J. (2000). T-Coffee: a novel method for fast and accurate multiple sequence alignment. J Mol Biol 302, 205-217.

Oshima, K., Kakizawa, S., Nishigawa, H., Kuboyama, T., Miyata, S., Ugaki, M. \& Namba, S. (2001). A plasmid of phytoplasma encodes a unique replication protein having both plasmid- and virus-like domains: clue to viral ancestry or result of virus/plasmid recombination? Virology 285, 270-277.

Ranhand, J. M., Mitchell, W. O., Popkin, T. J. \& Cole, R. M. (1980). Covalently closed circular deoxyribonucleic acids in spiroplasmas. $J$ Bacteriol 143, 1194-1199.

Renaudin, J. (2002). Extrachromosomal elements and gene transfer. In MolecularBiology and Pathogenicity of Mycoplasmas, pp. 347-370. Edited by S. Razin \& R. Herrmann. New York: Kluwer Academic/Plenum.

Renaudin, J. \& Lartigue, C. (2005). OriC plasmids as gene vectors for mollicutes. In Mycoplasmas: Pathogenesis, Molecular Biology, and Emerging Strategies for Control, pp. 3-30. Edited by A. Blanchard \& G. Browning. Norwich, UK: Horizon Scientific Press.

Renaudin, J., Marais, A., Verdin, E., Duret, S., Foissac, X., Laigret, F. \& Bové, J. M. (1995). Integrative and free Spiroplasma citri oriC plasmids: expression of the Spiroplasma phoeniceum spiralin in Spiroplasma citri. J Bacteriol 177, 2870-2877.

Saglio, P., Laflèche, D., Bonisol, C. \& Bové, J. M. (1971). Culture in vitro des mycoplasmes associés au stubborn des agrumes et leur observation au microscope électronique. C R Acad Sci Paris 272, 1387-1390.

Saglio, P., Lhospital, M., Laflèche, D., Dupont, G., Bové, J. M., Tully, J. G. \& Freundt, E. A. (1973). Spiroplasma citri gen. and sp. nov.: a mycoplasma-like organism associated with stubborn disease of citrus. Int J Syst Bacteriol 23, 191-204.

Saillard, C., Vignault, J. C., Bové, J. M., Raie, A., Tully, J. G, Williamson, D. L., Fos, A., Garnier, M., Gadeau, A., Carle, P. \& Whitcomb, R. F. (1987). Spiroplasma phoeniceum sp. nov., a new plant pathogenic species from Syria. Int J Syst Bacteriol 37, 106-115.

Saillard, C., Carle, P., Duret-Nurbel, S., Henri, R., Killiny, N., Carrère, S., Gouzy, J., Bové, J. M., Renaudin, J. \& Foissac, X. (2008). The abundant extrachromosomal content of Spiroplasma citri strain GII3-3X. BMC Genomics 9, 195-207.

Salvado, J. C., Barroso, G. \& Labarere, J. (1989). Involvement of a Spiroplasma citri plasmid in the erythromycin-resistance transfer. Plasmid 22, 151-159.

Sirand-Pugnet, P., Lartigue, C., Marenda, M., Jacob, D., Barré, A., Barbe, V., Schenowitz, C., Mangenot, S., Couloux, A. \& other authors (2007). Being pathogenic, plastic, and sexual while living with a nearly minimal bacterial genome. PLoS Genet 3, e75.

Stamburski, C., Renaudin, J. \& Bové, J. M. (1991). First step toward a virus-derived vector for gene cloning and expression in spiroplasmas, organisms which read UGA as a tryptophan codon - synthesis of chloramphenicol acetyltransferase in Spiroplasma citri. J Bacteriol 173, 2225-2230.

Stewart, P. E., Byram, R., Grimm, D., Tilly, K. \& Rosa, P. A. (2005). The plasmids of Borrelia burgdorferi: essential genetic elements of a pathogen. Plasmid 53, 1-13.

Thompson, J. D., Higgins, D. G. \& Gibson, T. J. (1994). CLUSTAL W: improving the sensitivity of progressive multiple sequence alignment through sequence weighting, position-specific gap penalties and weight matrix choice. Nucleic Acids Res 22, 4673-4680. 
Tran-Nguyen, L. T. \& Gibb, K. S. (2006). Extrachromosomal DNA isolated from tomato big bud and Candidatus Phytoplasma australiense phytoplasma strains. Plasmid 56, 153-166.

Vignault, J. C., Bové, J. M., Saillard, C., Vogel, R., Faro, A., Venegas, L., Stemmer, W., Aoki, S., McCoy, R. E. \& other authors (1980). Mise en culture de spiroplasmes à partir de matériel végétal et d'insectes provenant de pays circum méditerranéens et du Proche Orient. $C R$ Acad Sci Paris 290, 775-780.

Vivian, A., Murillo, J. \& Jackson, R. W. (2001). The roles of plasmids in phytopathogenic bacteria: mobile arsenals? Microbiology 147, 763-780.

Weisburg, W. G., Tully, J. G., Rose, D. L., Petzel, J. P., Oyaizu, H., Yang, D., Mandelco, L., Sechrest, J., Lawrence, T. G. \& other authors (1989). A phylogenetic analysis of the mycoplasmas: basis for their classification. J Bacteriol 171, 6455-6467.

Whitcomb, R. F. (1983). Culture media for spiroplasma. In Methods in Mycoplasmology, vol. I, pp. 147-158. Edited by S. Razin \& J. G. Tully. New York: Academic Press.
Whitcomb, R. F., Chen, T. A., Williamson, D. L., Liao, C., Tully, J. G., Bové, J. M., Mouchès,, C., Rose, D. L., Coan, M. E. \& Clark, T. B. (1986). Spiroplasma kunkelii sp. nov.: characterization of the etiologic agent of corn stunt disease. Int J Syst Bacteriol 36, 170-178.

Williamson, D. L., Whitcomb, R. F., Tully, J. G., Gasparich, G. E., Rose, D. L., Carle, P., Bové, J. M., Hackett, K. J., Adams, J. R. \& other authors (1998). Revised group classification of the genus Spiroplasma. Int J Syst Bacteriol 48, 1-12.

Ye, F., Renaudin, J., Bove, J. M. \& Laigret, F. (1994). Cloning and sequencing of the replication origin (oriC) of the Spiroplasma citri chromosome and construction of autonomously replicating artificial plasmids. Curr Microbiol 29, 23-29.

Yu, J., Wayadande, A. C. \& Fletcher, J. (2000). Spiroplasma citri surface protein P89 implicated in adhesion to cells of the vector Circulifer tenellus. Phytopathology 90, 716-722.

Edited by: I. K. Toth 